\title{
FLOATING MAXIM IN TV SHOW : RUMPI NO SECRET
}

\author{
Nena Nurjannah ${ }^{1}$, Riris Resti Fujianti ${ }^{2}$ \\ ${ }^{1}$ IKIP Siliwangi \\ ${ }^{2}$ IKIP Siliwangi \\ ${ }^{1}$ nenanurjannah28@gmail.com, ${ }^{2}$ fujiantiririsresti@gmail.com
}

\begin{abstract}
The purpose of this study is to identify the techniques that lecturers use in assessing a conversation. Then to discover how the English lecturer makes conversation judgments using pragmatic techniques. several video conversations were selected as data in this study. The data obtained from the results observed a video on gossip tv shows and then in transcript and reported descriptive. The results of this study showed in a tv show there are several violations of maxim according to pragmatic techniques. From start violation of maxim quantity, quality, manner and relation. sources taken from a video on a tv show that talks about gossip and internet.
\end{abstract}

Keywords: Floting, Maxim, Video on Gossip TV Show

\section{INTRODUCTION}

There are many fields which can be seen dealing with the role of English, such as: technology, health, tourism, correspondence, etc. In Indonesia, English is taught from Elementary School up to University Level. This indicates that English becomes important as an International Language and majority used by people all over the world (Mundriyah and Parmawati, 2016).Therefore, English is taught from elementary to higher education. As stated by Defianty (2007) that the success of a learning program as is usually determined by the outcome of judgment. Generally, teachers use tests as the best tool for measuring the ability of their learners .

Grice proposes that in ordinary conversations, speakers and listeners share the principle of cooperation. Speakers form their speech to be understood by listeners and listeners are expected to provide the expected answers. So, in to make a good conversation, there will be a proverbial conversation that makes a good conversation go well. Conversational Maxims good conversations are developed by the cooperation they create. They must comply with some of the rules referred to as the conversation maxim mentioned above. They are also sometimes named Grice or Gricean maxim. Based on the description above, this study aims to identify the techniques used in the lecturer assessing speech comprehension and finding ways the English lecturer makes speaking judgments. Pragmatics also has various sub-studies, one of them is Cooperative Principle. Grice (1975) as a philosopher of linguistics developed a model called as Cooperative Principles which human being follows to ensure successful communication. These principles can make the conversation work effectively and run smoothly. The people actually have followed this principle unconsciously in their daily life conversation. But in fact, there are many people who disobey this principle. According to Grice (1975), the purpose of the principle of cooperation is to get an effective and informative communication as it is clear. It has four maxims; they are quantity maxim, quality maxim, relation. 
Television shows are a series of related productions intended for broadcast on the air, cable television or internet television, in addition to advertisements, trailers or other content segments that do not serve as an attraction to viewers. More rarely, it may be a single production, also called television. A the number of episodes of a limited television show may be called a miniseries or a limited series or series. Television series do not have a fixed length and are usually divided into seasons (US and Canada) or series (UK), sets of new episodes every year or half yearly. Although there are no clear boundaries, US industry practice has traditionally favored the television season than any other country. A one-off broadcasts may be called "special" or especially in the UK "special episodes". Television movies ("movies made for TV" or "television movies") are films originally broadcast on television rather than being released in theaters or directly to videos. A program can be recorded, as in video tapes, various forms of other electronic media, played with on-demand players or viewed on live television broadcasts.

\section{Maxim and Its Types}

Maxim as part of the principle of cooperatives is the field of pragmatics. Maxim is the concept that leads to the making speakers contribution to a conversation. The concept of the adage is based on the philosophers (Grice, 1975) pragmatic account communication. As The atrium (2017) asserts that Grice identifies as guidelines of this sort four basic maxim of conversations or general principles underlying the efficient use of cooperative language.

Maxim of conversation is a general principle underlying the efficient use of cooperative language that together express the principles of common co-operatives. According to Grice (1975 cited Yule, 1996), there are four cooperative maxims principles:

\section{Maxim of Quantity}

Maxim of quantity is a maxim which leads to make the contribution in conversation as informative as needed. It is divided into two sub maxim, which (Grice, 1975) states as follows: "Make your contribution as informative as necessary (for current purposes exchange) and do not make your contribution more informative than that required."

\section{Maxim of Quality}

This maxim focused on the quality of information that is given by speaker. The speaker should try to make the contribution be true. Grice suggest two sub maxims: "Do not say what you believe is wrong and do not say that you do not have sufficient evidence. (Yule, 1996).

\section{Maxim of Relation}

Speakers' contribution must be clearly connected with purpose exchange, it should be relevant. The maxim of the relationship requires its relevance to the context and the circumstances in which it occurs. (Thomas, 1995)

\section{Maxim of Manner}

This proverb states that in order to achieve efficient communication, we must be "sharp" and specifically (1) avoid obscurity, (2) avoid ambiguity, (3) be short (avoid unnecessary prolixity), and (4) regular. According to this maxim, speakers and listeners must be clear in contributing to the exchange of communication. They also have to complete their performance with reasonable dispatch. 


\section{METHOD}

This research used descriptive qualitative research. Referring to the objective of this study, the design is considered appropriate since it is a method used to describe or analyze the results of the study (Sugiyono, 2005, as cited in Apsari, 2017). According to Creswell (2012, cited in Aryana and Apsari, 2018), "Analyzing qualitative data requires understanding how to make sense of text and image, so that you can form answers to your research questions". In addition, in analyzing the data, the researcher integrated and related the findings to the background of the study, mainly to the research questions, theories, and the methodology for classifying the data into manageable units as suggested by Emilia (2008, in Apsari, 2018).

\section{RESULTS AND DISCUSSION}

\section{Results}

In this situation that we knew about the technology and the globalization era so rapidly that in communicating it is not only include Indonesian language but must understand about other foreign languages as well as English. therefore the author is interested to discuss vocabulary because it becomes a supporting factor in language communication, especially in English. but in this case the authors intend to help students with special needs in language, especially for deaf children with poster learning method because they are limited with hearing and difficult to speak or argue thoroughly in understanding vocabulary itself and how important it is a factor in language support.

\begin{tabular}{|c|c|c|c|c|}
\hline No & Name & Motivation & Interest & Active \\
\hline 1 & Student 1 & $\begin{array}{l}\text { having a vocabulary } \\
\text { understanding that is } \\
\text { quite prominent } \\
\text { among the others }\end{array}$ & $\begin{array}{l}\text { from the test results } \\
\text { given, most } \\
\text { significantly increased } \\
\text { understanding } \\
\text { vocab }\end{array}$ & $\begin{array}{l}\text { quite active in the } \\
\text { class,confident, } \\
\text { quickly responding } \\
\text { to responsiveness to } \\
\text { the material } \\
\text { presented. }\end{array}$ \\
\hline
\end{tabular}

\begin{tabular}{|c|c|c|c|c|}
\hline 2 & Student 2 & $\begin{array}{lr}\text { has a good } & \text { a } \\
\text { understanding } & \text { of } \\
\text { vocabulary, given. }\end{array}$ & $\begin{array}{l}\text { have an increase in } \\
\text { understanding from } \\
\text { the test results vocab }\end{array}$ & $\begin{array}{l}\text { lack of confidence in } \\
\text { conveying something }\end{array}$ \\
\hline 3 & Student 3 & $\begin{array}{l}\text { The understanding of } \\
\text { vocab given } \\
\text { sometimes forgot } \\
\text { again, so reminded, } \\
\text { just remember again. }\end{array}$ & $\begin{array}{l}\text { can immediatel } \\
\text { y understand the } \\
\text { material presented }\end{array}$ & $\begin{array}{l}\text { given the test, and } \\
\text { given a little } \\
\text { explanation, quickly } \\
\text { responsive }\end{array}$ \\
\hline
\end{tabular}




\begin{tabular}{|c|c|c|c|c|}
\hline No & Name & Motivation & Interest & Active \\
\hline 4 & Student 4 & $\begin{array}{l}\text { just forget it often, and } \\
\text { must often be } \\
\text { reminded or repeated }\end{array}$ & $\begin{array}{l}\text { the test results given } \\
\text { have an increase about } \\
\text { vocabulary } \\
\text { understanding. }\end{array}$ & active in learning, \\
\hline 5 & Student 5 & $\begin{array}{l}\text { must also be reminded } \\
\text { again often, easy to } \\
\text { forget, a day } \\
\text { understand, } \\
\text { tomorrow asked to } \\
\text { forget } \\
\text { reminded, again, } \\
\text { remember }\end{array}$ & $\begin{array}{l}\text { from the test results } \\
\text { there is an increase in } \\
\text { change. }\end{array}$ & $\begin{array}{l}\text { good enough in } \\
\text { classroom learning }\end{array}$ \\
\hline
\end{tabular}

\section{Discussion}

The research carried on the second grade at SMALB AL-Hikmah Padalarang for 6 meetings. for 6 meetings. The six meetings were categorized into 2 cycles. The result of each cycle will be organized on four steps of CAR, namely : (1) planning, (2) acting, (3) observing, and (4) reflecting.

Cycle 1 On planning section, the researchers prepared some lesson plans to teach vocabularies and put them into a poster. Lesson plans were made to be implemented on treatment1, and 2, which contained some procedures in classification of some word into the poster.In this cycle, the researchers found some problems of learning process and prepared for next meeting to be better strategies. Six meeting, the researchers provided some word to arranged by students. The steps of acting and observing are displayed on table 1 below :

Table 1. Meetings in Cycle 1

\begin{tabular}{|c|c|c|}
\hline \multicolumn{2}{|r|}{ Acting } & Observing \\
\hline Meeting & Topic & Activity \\
\hline 1 & $\begin{array}{l}\text { Practice } 1: \\
\text { stick word on poster }\end{array}$ & $\begin{array}{l}\text { In this first meeting, the researchers give them a pre- } \\
\text { test which consist of the meaning of words (subject), } \\
\text { noun, and verb. }\end{array}$ \\
\hline 2 & $\begin{array}{l}\text { Treatment } 1: \\
\text { Classification the words } \\
\text { on the poster. }\end{array}$ & $\begin{array}{l}\text { The students try to understand about the material one } \\
\text { by one. Students learn the material with some visual } \\
\text { media and make them easy to remember the material, } \\
\text { the students come in front to the class for classifing the } \\
\text { word one by one. }\end{array}$ \\
\hline 3 & $\begin{array}{l}\text { Treatment } 2 \text { : } \\
\text { Arrange the word to be a } \\
\text { good sentence. }\end{array}$ & $\begin{array}{l}\text { In this meeting, the teacher give some word about } \\
\text { subject, noun, and verb. every students work } \\
\text { individualy to arrange the word to be a good sentences } \\
\text { and understanding the meaning of that senteces. } \\
\text { Students try to write the sentences in front of class } \\
\text { atwhiteboard. Students do this activity using poster. }\end{array}$ \\
\hline
\end{tabular}




\begin{tabular}{cll}
\multicolumn{2}{c}{ Acting } & \multicolumn{1}{c}{ Observing } \\
\hline Meeting & \multicolumn{1}{c}{ Topic } & \multicolumn{1}{c}{ Activity } \\
\hline 4 & $\begin{array}{l}\text { Practice } 2: \\
\text { Write } 5 \text { sentences using } \\
\text { words on the poster. }\end{array}$ & $\begin{array}{l}\text { In this meeting, the researchers conducted post-test } \\
\text { which consists } 5 \text { number of test and intruction them to } \\
\text { write } 5 \text { sentences using words that has been provide. } \\
\text { The questions presented in the same form and level of } \\
\text { difficulty with the pre-test. }\end{array}$ \\
\hline
\end{tabular}

Therefore, the cycle II was carried out to continue the research.

Cycle II. This cycle only covered four steps as stated in cycle I. In planning session, theresearchers made some revision towards lesson plans. On the previous treatment, some students be an active. The acting session covered three meetings, since the practice 1 used for this cycle was taken from the practice 2 from the previous cycle as seen on table 2 below :

Table 2 Meetings in cycle II

\begin{tabular}{cll}
\hline Meeting & \multicolumn{1}{c}{ Acting } & \multicolumn{1}{c}{ Topic } \\
\hline $\mathbf{5}$ & $\begin{array}{l}\text { Treatment 3: } \\
\text { Understanding words on } \\
\text { poster. }\end{array}$ & $\begin{array}{l}\text { Observing } \\
\text { Activity } \\
\text { students more understanding. Repeat and repeat } \\
\text { again in this learning process. And ask to every } \\
\text { student words about subject verb and noun one } \\
\text { by one, for make sure that they understand. }\end{array}$ \\
\hline $\mathbf{6}$ & $\begin{array}{l}\text { Treatment } 4: \\
\text { Understanding } \\
\text { sentences from word at the } \\
\text { poster. }\end{array}$ & $\begin{array}{l}\text { On this treatment, students analize the sentences } \\
\text { which as a subject, verb and noun. Students } \\
\text { search what the meaning of the sentences and } \\
\text { understand it. }\end{array}$
\end{tabular}

\section{CONCLUSION}

Based on the data analysis and the result of discussion of findings, it can be concluded that the poster media can improve students' especially in learning english vocabulary to deaf students' at SMALB AL-HIKMAHFrom the result of this study some sugesstion to note include:

1. using poster media in teaching english vocabulary is recommended for english teachers, especially for deaf students, teachers to attract the students interest in learning english. And By using series picture as media. The students are suggested to be better to learning in English vocabulary.

2. the teachers has to use some variants of media in teaching english so the students felt the interest in learning. To arising and increasing students English learning, the teacher must be creative, do not rely on textbook, and uses the media.

2. for the other researchers to conduct other research on the same field using the other form of poster media applied in other skills, such as: listening, speaking, reading and writing 


\section{REFERENCES}

Apsari, Y. (2017). The Use of Picture Series In Teaching Writing Recount Text. Eltin Journal, Journal of English Language Teaching in Indonesia, 5(2), 51-56.

Apsari, Y. (2018). Reflective Reading Journal In Teaching Writing. Indonesian EFL Journal, 4(2), 39-47.

Aryana, S., \& Apsari, Y. (2018). Analysing Teacher's Difficulties In Teaching Listening. Eltin Journal, Journal of English Language Teaching in Indonesia, 6(2), 100-106.

Creswell, J. (2014). A Concise Introduction to Mixed Methods Research.. Retrieved July 5, 2018 ,

https://books.google.co.id/books?hl=id\&lr=\&id=51UXBAAAQBAJ\&oi=fnd\&pg=PR1\& $\mathrm{dq}=$ creswell+2014+research+design+qualitative+quantitative+and+mixed+methods+app roaches\&ots $=69 \mathrm{FnR} 5 \mathrm{VtOx} \& \operatorname{sig}=\mathrm{OyfMUbNLO} 2 \mathrm{uzWbsnqumsFmTj2nw \& redir}=\mathrm{esc}=\mathrm{y} \# \mathrm{v}$ $=$ onepage $\& \mathrm{q}=$ creswell 2014 resear

Hiebert, E. H., \& Kamil, M. L. (2005). Teaching and Learning Vocabulary. New York: Routledge.

Mason.j. (2002). Qualitative Researching - Jennifer Mason - Google Buku (second). Los Angels : sage publication ltd.

Mundriyah, M., \& Parmawati, A. (2016). Using Think-Pair-Share (Tps) To Improve Students'writing Creativity (A Classroom Action Research in the Second Semester Students of STKIP Siliwangi Bandung). P2M STKIP Siliwangi, 3(2), 84-91.

Padden, Carol; Ramsey, C. (1997). Deaf Students as Readers and Writers: A Mixed-Mode Research. Educational Resources Information Center (ERIC). Retrieved from https://files.eric.ed.gov/fulltext/ED413688.pdf

Richards, J., \& Schmidt, R. (2002). Longman Dictionary of Language Teaching. New York: Routledge.

Thalib S.B. (2010). Psikologi Pendidikan Berbasis Analisis Empiris Aplikatif - Prof. Dr. Syamsul Bachri Thalib, M.Si. - Google Buku (1st ed.). JAKARTA: Kencana Media Group. 